\title{
Zika Virus Infection and Psychiatric Problem: A Short Summary
}

\author{
Viroj Wiwanitkit ${ }^{1,2,3,4,5}$ \\ ${ }^{1}$ Visiting professor, Hainan Medical University, China; \\ ${ }^{2}$ Honorary professor, Dr DY Patil University, India; \\ ${ }^{3}$ Professor, senior expert, Surindra Rajabhat University, Thailand; \\ ${ }^{4}$ Adjunct professor, Joseph Ayobabalola University, Nigeria; \\ ${ }^{5}$ Visiting professor, Faculty of Medicine, University of Nis, Serbia.
}

*Corresponding to: Professor Viroj Wiwanitkit, Wiwanitkit House, Bangkhae, Bangkok Thailand. Email: wviroj@yahoo.com.

\begin{abstract}
Zika virus infection is the present global medical issue. Due to its worldwide spreading, the disease is still the big public health problem. There are many reports on the neuropathology due to the Zika virus infection. The psychiatric problem due to Zika virus infection is very interesting. In this short article, the author summarizes the data on psychiatric problem relating to Zika virus infection.
\end{abstract}

Key words: Zika virus; infection; psychiatry

\section{INTRODUCTION}

Zika vitrus is an arboivirus that can cause the illness in human beings. At present, Zika virus infection is the present global medical issue. It is accepted as a big public health problem at present. The Zika virus infection already spread throughout the world affected many millions people. The primary sets of outbreaks occur in Pacific area in 2007 then the disease occurred in South America in 2015 and become the big problem in that area ${ }^{[1]}$. After its large outbreak in Pacific and South America, Zika infection presently becomes the disease under surveillance around the world ${ }^{[1]}$. There are several ways that Zika virus can be transmitted including to mosquito bite and sexual contact. There is still no specific antiviral drug and vaccine against Zika virus. The infection is still a present global challenge. Due to its worldwide spreading, the disease is still the big public health problem ${ }^{[2]}$. In general, the disease is a dengue like illness. But it can induce the infant abnormality in case of vertical transmission. It can also induce the neurological problem in adult patients. There are many reports on the 
neuropathology due to the Zika virus infection. The neurological deficit in affected infant who get vertical transmission and the Guillain-Barre syndrome in infected adult are the big issue in clinical neurology ${ }^{[3,}$ 4]. The psychiatric problem due to Zika virus infection is very interesting. In this short article, the author summarizes the data on psychiatric problem relating to Zika virus infection.

\section{PSYCHIATRIC PROBLEM DUE ZIKA VIRUS INFECTION}

Although there are many reports on neuropathology due to Zika virus infection, there is still no clear evidence of psychiatric problem relating to Zika virus infection. It is proposed that the case with congenital Zika virus syndrome might have mental retardation or other mental disorders ${ }^{[5,6]}$. Nevertheless, as a new emerging disease, the final conclusion needs a long-term follow-up. There is still very few data on the psychiatric problem in infants with Zika virus disease. In adult cases who have neurological complication, the alteration of consciousness is possible ${ }^{[7]}$. In case with Zika virus encephalopathy, delirium ${ }^{[8]}$ and seizure can be observed ${ }^{[9,10]}$. Hence, it is no doubt that the patient might firstly present with neuropsychiatric signs and symptoms.

Another interesting consideration is on the occurrence of Zika virus infection in the patients with underlying psychiatric disorder such as Schizophrenia. There is a possibility and it can be a big challenge in anti-psychiatric drug administration, similar to the case with other similar arbovirus infection ${ }^{[11]}$. The unwanted possible adverse effect of using anti-psychiatric drug in the psychiatric patient is the sever neutropenia ${ }^{[8]}$. The closed monitoring for complete blood count in psychiatric patient who gets arbovirus infection including to Zika virus infection is needed.

Although the direct effect of virus infection might not lead to the psychiatric problem, the infection might have the psychiatric impact. It is no doubt that the pregnant, who got infection during pregnancy and give birth to abnormal child, will get psychiatric suffering ${ }^{[11,12]}$. Dos Santos Oliveira et al. noted that there was a need for psychological support to the infected mothers and the support should continue in case that the mother has abnormal child ${ }^{[13,14]}$.

For ones who do not get infection, anxiety and panic can also be seen ${ }^{[14]}$. The good education and panic management is also a need in counteracting with emerging Zika virus infection.

\section{CONCLUSION}

Zika virus infection is a big problem in public health. The psychiatric problem relating to Zika virus infection is an interesting issue but there are few data. It is an interesting topic for further observations and studies. There is an urgent research needs and intervention globally for Zika virus infection covering all clinical aspects including to psychiatric problem.

\section{CONFLICT OF INTEREST}

None

\section{REFERENCES}

1. Sharma S, Tandel K, Dash PK, Parida MM. Zika virus: A public health threat. J Med Virol. 2017;doi:10.1002/jmv.24822.

2. Wiwanitkit V. The current status of Zika virus in Southeast Asia. Epidemiol Health. 2016;38:e2016026.

3. Duca LM, Beckham JD, Tyler KL, Pastula DM. Zika Virus Disease and Associated Neurologic Complications. Curr Infect Dis Rep. 2017;19(1):4.

4. Smith DE, Beckham JD, Tyler KL, Pastula DM. Zika virus disease for neurologists. Neurol Clin Pract. 2016;6(6):515-522.

5. Torales J, Barrios I. The Zika virus beyond microcephaly: will we face an increase in mental disorders? Medwave. 2017;17(1):e6869.

6. Miranda-Filho Dde B, Martelli CM, Ximenes RA, Araújo TV, Rocha MA, Ramos RC, Dhalia $\mathrm{R}$, França RF, Marques Júnior ET, Rodrigues LC. Initial Description of the Presumed Congenital Zika Syndrome. Am J Public Health. 2016;106(4):598-600.

7. Falcao MB, Cimerman S, Luz KG, Chebabo A, Brigido HA, Lobo IM, Timerman A, Angerami RN, da Cunha CA, Bacha HA, Alves JR, Barbosa AN, Teixeira RF, Weissmann L, Oliveira PR, Cyrillo MA, Bandeira AC. Management of infection by the Zika virus. Ann Clin Microbiol 
Antimicrob. 2016;15(1):57.

8. Rozé B, Najioullah F, Signate A, Apetse K, Brouste 9.Y, Gourgoudou S, Fagour L, Abel S, Hochedez P, Cesaire R, Cabié A; NeuroZika Working Group of Martinique. Zika virus detection in cerebrospinal fluid from two patients with encephalopathy, Martinique. Euro Surveill. 2016;21(16):30154.

9. Asadi-Pooya AA. Zika virus-associated seizures. Seizure. 2016;43:13.

10. Wiwanitkit V. Seizure and Zika virus infection. Seizure. 2017;45:1.

11. Nunes EA, Rezende TM, Morais SL, Crippa JA, Dursun SM, Baker GB, Hallak JE. Clozapine treatment of patients with refractory schizophrenia, concurrent dengue infection and hematological abnormalities: three case reports.
Ther Adv Psychopharmacol. 2013;3(2):83-88.

12. Dos Santos Oliveira SJG, Dos Reis CL, Cipolotti R, Gurgel RQ, Santos VS, Martins-Filho PRS. Anxiety, depression, and quality of life in mothers of newborns with microcephaly and presumed congenital Zika virus infection: a follow-up study during the first year after birth. Arch Womens Ment Health. 2017;20(3):473-475.

13. Dos Santos Oliveira SJ, de Melo ES, Reinheimer DM, Gurgel RQ, Santos VS, Martins-Filho PR. Anxiety, depression, and quality of life in mothers of newborns with microcephaly and presumed congenital Zika virus infection. Arch Womens Ment Health. 2016;19(6):1149-1151.

14. Grubaugh ND, Andersen KG. Navigating the Zika panic. F1000Res. 2016;5:1914. 